\title{
Emotional Intelligence And Life Adjustment For Nigerian Secondary Students
}

Obioma Helen Ogoemeka, University of Nigeria, Nsukka, Nigeria

\begin{abstract}
In the process of educating adolescents, good emotional development and life adjustment are two significant factors for teachers to know. This study employed random cluster sampling of senior secondary school students in Ondo and Oyo States in south-western Nigeria. The Random sampling was employed to select 1,070 students. The data collected were analyzed using means, standard deviation and factor analysis. Significant differences were found between students in Ondo and Oyo States concerning emotional intelligence (EI) and life adjustment (LA). Moreover, senior secondary school students in Ondo did not show significant differences in EI, according to several background variables, but their parenting style was associated with significant differences in terms of LA. Furthermore, of the background variables measured, only the factor of parents' marital status was not significantly different in terms of EI of senior secondary school students in Oyo. There was no significant difference in those students' EI according to birth order. A positive and modest correlation was found between EI scores of students in Ondo and Oyo. On the basis of the findings of this study, the researcher recommended that: educators in these schools implement a student consulting program to reinforce students' abilities of emotional control and to; provide gender education for mutual learning to help students learn how to deal with people. Moreover, teachers should integrate daily interaction with more diverse people in order to improve selfunderstanding.
\end{abstract}

Keywords: Emotional Intelligence; Life Adjustment; Nigeria; Parenting Style; Birth Order, Adolescents

\section{INTRODUCTION}

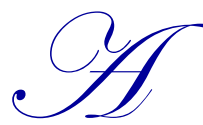

s family is no longer guaranteed to offer children (of which there are a growing number) a sure footing in life, schools are left as the one place to which communities can turn in order to correct children's deficiencies in emotional and social competence. That is not to say that schools alone can substitute for all of the social institutions that are too often in or nearing a state of collapse. However, since virtually every child goes to school (at least at the outset), schools offer a place to reach children with basic life lessons that they may never otherwise receive. Emotional literacy implies an expanded mandate for schools, demanding that they pick up the slack for families that fail to socialize children (Goleman, 1995). This daunting task requires two major changes; teachers need to go beyond their traditional mission and people in the communities need to become more involved with schools.

Nowadays, school education places more emphasis on the learning of knowledge rather than on students' frame of mind. Yet students feel nervous, anxious, frustrated, depressed, and abased when instructors ignore their emotions. If students cannot receive timely guidance from school authorities, teachers or their parents, or timely concern from their peers or siblings, then their unstable emotions may result in behavioral problems. Furthermore, mental disorders can influence students' academic achievement and life adaptation.

Students in senior secondary school are in their second decade of life, which is marked by the onset of puberty. According to Stanley Hall, this is a period characterized by "storm and stress". Clearly, there is reason to be concerned about the well-being of early adolescents. Educators often underestimate the importance of developing students' abilities to adapt and get along with people; however, students' learning abilities depend on their abilities to adapt and cope with people (Elias, 2001). 
The rapidness of changes during this period and the growing complexity of life changes have made understanding and mastery of emotions increasingly important. Strong negative emotions, such as fear, worry, distress, and anger can be injurious to health if not properly managed. In order to avoid the damaging effects of emotions, and to harness the creative potential of the effective use of emotions, it is important that one be emotionally intelligent. According to Castella (2001), "[what really matters for success character, happiness and... life-long achievement is a definable set of emotional skills...]" (p. 29). Leaders in the workplace or school, and outstanding performers are not defined or known by their intelligent quotients (I.Q) or even their job skills, but by their [emotional intelligence] (Yong, 2001).

Goleman (1995) popularized the construct of emotional intelligence, which was first used by Salovey and Mayer (1990) to describe individuals' ability to perceive, express, use, understand, and regulate emotions in themselves and others. It can be defined as the capacity to monitor emotions in yourself and others, to discriminate among emotions, to understand messages in emotions, and to use energy in emotions for personal gains and fulfillment (Ogunyemi, 2008). In other words, it refers to the intelligent use of emotions to make them work for one by using them to help guide one's results. Akinboye, (2003) proposed that emotional intelligence works synergistically with IQ to enhance human performance. It is what differentiates exceptional from mediocre performance.

Adjustment connotes conformity; it deals with the way an individual adapts to his/her environment and the demands of life. This includes how he/she relates to others (interpersonal) and how he/she deals with his/her responsibilities and inner feelings. Psychologically, adjustment helps the organism to cope with the demands and pressures of the outside world as well as the needs, desires, and conflicts experienced from within (Dickens, 2006). According to researchers, adjustment is a life-long process and is a factor in everything that we do.

In short, confidence and positivity when seeking to solve problems are the core factors for good emotional development and life adaptation. Educators often underestimate the importance of these demands, but, in reality, children's energy for learning depends on the nature of these coping experiences. When adolescents enter junior high school, the problems they confront may challenge their coping skills and are often the main reason for the fact that they experience pressure. Thus, it is important that secondary school education brings with it opportunities and demands to learn, adapt and cope (Elias, 2001).

The main purposes of this study were the following:

- $\quad$ To determine whether there are differences in emotional intelligence between senior secondary school students in Ondo and Oyo States;

- $\quad$ To determine whether there are differences in life adjustment between senior secondary school students in Ondo and Oyo States;

- To examine the differences in students' emotional intelligence and life adjustment according to different background variables;

- $\quad$ To identify any correlations between emotional intelligence and life adjustment among senior secondary school students.

\section{METHOD}

A descriptive survey research design in which the researcher collected data from the respondents by means of questionnaires was employed in this study.

\section{Framework}

The framework of this study is shown in Figure 1 below. This indicates the relationships between the independent and dependent variables 


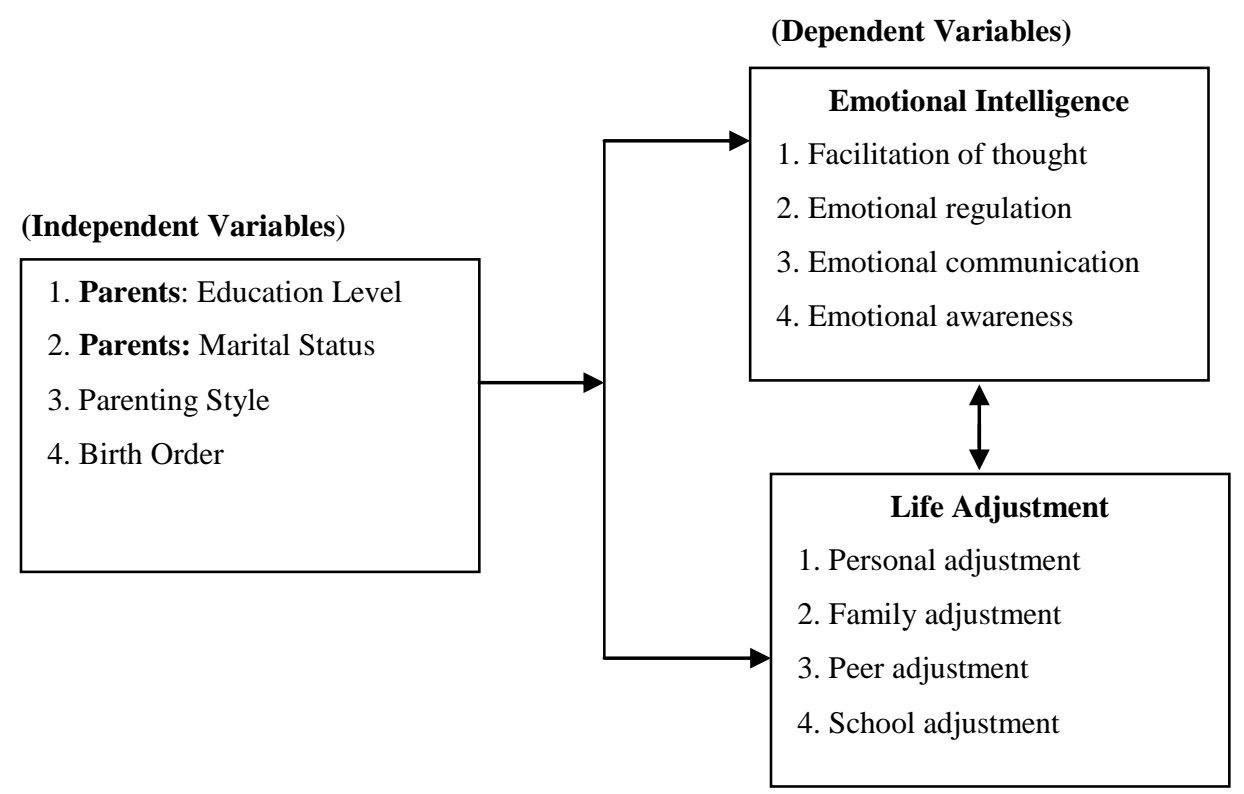

Figure 1: Framework of the research

\section{Participants}

The participants in this study were 1,070 a thousand final year senior secondary school students (500 male, 570 female) selected by random cluster sampling from 15 randomly selected mixed secondary schools in Ondo and Oyo States in southwestern Nigeria. The age range of the students was 13 to 19 years, with a mean of 16.5 years and a standard deviation of 2.08 .

\section{Instruments}

Two research instruments were used in this study. These were emotional intelligence inventory (EII) and the life adjustment inventory (LAI). The instruments were evaluated by five experts in the field in order to ensure their validity. These inventories utilized a 5-point scale according to the scale anchors; very good, good, average, poor, and very poor: these responses were assigned values of 5,4,3,2 and 1 respectively. The Cronbach's alpha coefficients of the EII were between 0.87 and 0.93 for each subscale and 0.91 for the total EII score.

The Cronbach's alpha coefficients of the LAI were between 0.90 and 0.94 for each subscale, and 0.92 for the total LAI score.

\section{EII}

The EII incorporates four factors (Mayer \& Salovey, 1997). The first is facilitating thought, which is; the ability to perceive emotions, think, choose, plan, solve problems, inspire, and improve one's self-maturity. The second factor is emotional regulation, which is; the ability to control one's emotions, maintain positive emotions, and be confident and cautious when solving problems. The third factor of the EII is emotional communication, which is the ability to: express one's true feelings and deal with problems appropriately. The fourth factor is emotional awareness, which is: the ability to be open to feelings, understand their truth, and be aware of others' emotions.

\section{$L A I$}

Life adjustment refers to a process whereby individuals interact with the environment to meet physical, psychological, and social needs and achieve a harmonious state (Tallent, 1978). The LAI includes the following four factors: 
Personal adjustment: an individual's ability to know one's potential conditions, emotions, and motivations behind certain behavior, and to appreciate the value of oneself and others and accept others' affection. Family adjustment: solving familial problems and the degree of happiness. Peer adjustment: admiring others, avoiding conflict, behaving appropriately, socializing with friends, being willing to help others, etc. School adjustment: academic achievement and individual progress, obeying school and class rules (Derlega \& Tanda, 1986).

\section{Background Variables}

In Previous research, emotional intelligence has been related to parents' level of education, the stability of their marital status, parenting style, familial atmosphere and family relation (Goleman, 1995; Gottman, Katz \& Hooven, 1997). In sum, the study used parents' education, marital status, parenting style, and the birth order among siblings as independent variables for further investigation.

\section{Data Analysis}

The data were analyzed using means, standard deviations and factor analysis. Orthogonal rotation was conducted using the varimax method (Wanichbuncha, 2001). Those items whose commonalities had Eigen-values of $>1$ were retained. Pearson correlation coefficients were employed to the indicate relationships between variables. The threshold for statistical significance was set at the 5\% level.

\section{RESULTS}

Table 1 illustrates the descriptive statistics obtained in the questionnaires given in Ondo and Oyo States.

Table 1: Sample Data $(\mathbf{N}=\mathbf{1 , 0 7 0})$

\begin{tabular}{|c|c|c|c|c|c|}
\hline \multirow{2}{*}{ Independent } & \multirow{2}{*}{ Item } & \multicolumn{2}{|c|}{ N (People) } & \multicolumn{2}{|c|}{ Percentage } \\
\hline & & Ondo & Oyo & Ondo & Oyc \\
\hline \multirow{3}{*}{$\begin{array}{l}\text { Parents' education } \\
\text { level }\end{array}$} & 1. Graduated secondary & 180 & 246 & 31.2 & 50.6 \\
\hline & 2. Secondary school & 299 & 196 & 50.8 & 40.9 \\
\hline & 3. Below junior High school & 105 & 43 & 18.4 & 8.6 \\
\hline \multirow{3}{*}{$\begin{array}{l}\text { Parents' marital } \\
\text { status }\end{array}$} & 1. Live together & 506 & 425 & 87.5 & 86.6 \\
\hline & 2. Separated/divorced & 45 & 64 & 8.2 & 12.8 \\
\hline & 3. Widow/widower & 14 & 16 & 3.3 & 3.4 \\
\hline \multirow[t]{3}{*}{ Parenting style } & 1. Democratic & 462 & 359 & 80.0 & 74.5 \\
\hline & 2. Indulgent & 97 & 63 & 16.8 & 13.1 \\
\hline & 3. Authoritative & 28 & 60 & 4.5 & 12.4 \\
\hline \multirow[t]{3}{*}{ Birth order } & 1. Eldest & 283 & 412 & 48.2 & 85.6 \\
\hline & 2. Middle & 117 & 30 & 20.4 & 6.1 \\
\hline & 3. Youngest & 188 & 40 & 32.3 & 8.3 \\
\hline
\end{tabular}

\section{Comparison}

The mean scores and standard deviations of each item and the t-test results are listed in Tables 2 and 3.

Table 2: T-test Results for Emotional Intelligence

\begin{tabular}{|l|c|c|c|c|c|}
\hline \multicolumn{1}{|c|}{ Factor } & Variable & n & Mean & SD & t \\
\hline Facilitating & Ondo & 588 & 46.54 & 6.46 & 6.12 \\
thought & Oyo & 482 & 48.40 & 6.04 & $-7.35^{* * *}$ \\
\hline Emotional & Ondo & 588 & 41.90 & 5.99 & $-3.90^{* * *}$ \\
regulation & Oyo & 482 & 42.34 & 5.54 & \\
\hline Emotional & Ondo & 588 & 39.32 & 5.91 & $-8.87 * * *$ \\
communication & Oyo & 482 & 41.44 & 5.35 & \\
\hline Emotional & Ondo & 588 & 41.02 & 5.29 & $-9.63 * * *$ \\
awareness & Oyo & 482 & 44.16 & 18.19 & \\
\hline Total & Ondo & 588 & 168.78 & 17.87 & -9.51 \\
\hline
\end{tabular}

$* * * \mathrm{p}<.001$ 
Table 2 shows a significant difference between students in Ondo and Oyo States in terms of their emotional intelligence. An independent two-tailed t-test revealed the difference in emotional intelligence between the students in Ondo and Oyo States to be statistically significant $(\mathrm{p}<0.05)$. The results showed that students in Oyo had significantly higher levels of emotional intelligence than those in Ondo.

Table 3: T-test Results for Life Adjustment

\begin{tabular}{|c|c|c|c|c|c|}
\hline Factor & Variable & n & Mean & SD & $\mathbf{t}$ \\
\hline Person & $\begin{array}{c}\text { Ondo } \\
\text { Oyo }\end{array}$ & $\begin{array}{l}588 \\
482\end{array}$ & $\begin{array}{l}24.16 \\
26.89\end{array}$ & $\begin{array}{l}4.16 \\
4.24\end{array}$ & $-10.62 * * *$ \\
\hline Family & $\begin{array}{c}\text { Ondo } \\
\text { Oyo }\end{array}$ & $\begin{array}{l}588 \\
482\end{array}$ & $\begin{array}{l}25.30 \\
26.38\end{array}$ & $\begin{array}{l}5.61 \\
6.32\end{array}$ & $-2.95 * *$ \\
\hline Peer & $\begin{array}{c}\text { Ondo } \\
\text { Oyo }\end{array}$ & $\begin{array}{l}588 \\
482 \\
\end{array}$ & $\begin{array}{l}23.77 \\
24.47 \\
\end{array}$ & $\begin{array}{l}4.17 \\
4.33 \\
\end{array}$ & $-2.74 * * *$ \\
\hline School & $\begin{array}{c}\text { Ondo } \\
\text { Oyo }\end{array}$ & $\begin{array}{l}588 \\
482 \\
\end{array}$ & $\begin{array}{l}23.71 \\
24.47 \\
\end{array}$ & $\begin{array}{l}4.17 \\
4.33 \\
\end{array}$ & $-2.74 * *$ \\
\hline Total & $\begin{array}{c}\text { Ondo } \\
\text { Oyo }\end{array}$ & $\begin{array}{l}588 \\
482 \\
\end{array}$ & $\begin{array}{c}98.65 \\
103.02 \\
\end{array}$ & $\begin{array}{l}12.54 \\
12.81 \\
\end{array}$ & $-6.90 * * *$ \\
\hline
\end{tabular}

Note $* * * \mathrm{p}<0.001 ; * * \mathrm{p}<0.01$

Table 3 lists the results of factor analysis and contain evaluations of the components: it showed that senior secondary students in Oyo State did significantly better in terms of life adjustment than those in Ondo state, $(\mathrm{p}<$ $0.05)$.

\section{Analysis of Variance (ANOVA)}

The average scores were analyzed using ANOVAs in order to find differences in the background variables between students in Ondo and Oyo States. The results of an ANOVA including the data of Ondo students showed that there were no significant differences in emotional intelligence according to variation in any of the background variables, i.e. parents' education level $\left(\mathrm{F}_{.95}(2,576)=2.27\right)$, parents' marital status $\left(\mathrm{F}_{.95}(2,576)=0.56\right)$, parenting style $\left(\mathrm{F}_{.95}(2.576)=2.37\right)$, and birth order $\left(\mathrm{F}_{.95}-(2,576)=0.02\right)$. A posteriori comparisons of Scheffe values indicate that a lower degree of education is better than a high degree of education for the emotional awareness factor of the EII $\left(\mathrm{F}_{.95}-(2,576)=4.67 *\right)$. Regarding parenting style, the results show that the democratic style is better than the indulgent style regarding the emotional factor $\left(\mathrm{F}_{\cdot 95}-(2,576)=3.93 *\right)$ of the EII.

Significant differences were found for the independent variables of emotional intelligence in Oyo, i.e., parents' education level $\left(\mathrm{F}_{.95}(2,480)=4.90^{*}\right)$, parenting style $\left(\mathrm{F}_{\cdot 95}(2,480)=7.23^{* *}\right)$ and birth $\operatorname{order}\left(\mathrm{F}_{.95}(2,480)=3.06^{*}\right)$. A posteriori comparisons of Scheffe values indicate that a higher degree of education is better than a lower degree of education for the emotional awareness factor of the EII in Oyo. Regarding parenting style, a posteriori comparisons of Scheffe values indicate that the democratic style is better than the authoritative style and that the indulgent style is better than the authoritative style for the EII emotional communication factor. It was found that being later in terms of birth order is better than being earlier in birth order for the emotional communication factor. No significant differences were found in terms of parents' marital status. A posteriori comparisons of Scheffe values indicate that having parents who live together is better than having parents that have undergone separation (or divorce) for students' emotional awareness $(\mathrm{F} \cdot 95-(2,480)=3.08 *)$.

The ANOVA results for Ondo students show no significant differences in life adjustment according to three independent variables, i.e., parents' education level $\left(\mathrm{F}_{.95-}(2,576)=0.93\right)$, parents' marital status $\left(\mathrm{F}_{.95}(2,576)=0.28\right.$ and birth order $\left(\mathrm{F}_{.95}(2,576)=0.03\right)$; however there were differences in terms of parenting style $\left(\mathrm{F}_{.95}(2,576)=6.94 * * *\right)$. A posteriori comparisons of Scheffe values indicate that the democratic style is not just better than the authoritative style, but also better than the indulgent style because democratic parents tends to be more communicative with their children.

The ANOVA results for Oyo students show no significant differences in life adjustment according to the independent variables, i.e. parents' education level $\left(\mathrm{F}_{.95}(2,480)=11.50 * * *\right)$ marital status $\left(\mathrm{F}_{.95}(2,480)=5.19 * *\right)$ and parenting style $\left(\mathrm{F}_{.95}(2,480)=9.45^{* * *}\right)$, however there were no significant differences in terms of birth order $(\mathrm{F} \cdot 95(2,480)$ 
= 1.69). A posteriori comparisons of Scheffe values show that a higher education level is better than a lower one, and that living together is better than separation (or divorce), for LAI results. For the parenting style factor, the democratic style is better than the authoritative and indulgent styles. Both family adjustment $(\mathrm{F} \cdot 95-(2,480)=9.39 * * *)$ and peer adjustment $\left(\mathrm{F}_{.95}(2,480)=8.05^{* * *}\right)$ achieved significant differences on the basis of birth order of siblings.

\section{DISCUSSION AND CONCLUSION}

Some conclusions can be drawn from the results of this study. Firstly, the average scores per item on the EII were 3.40 for Ondo students and 3.61 for Oyo students. This shows that both groups had good scores for every factor regarding emotional intelligence. This finding was consistent with those of Adeyemo (2004) and Farn, Ying, and Chia (2006). In order of scoring, the four EI factors were facilitating thought, emotional awareness, emotional regulation, and emotional communication.

Secondly, the average scores per item on the LAI were 3.28 for Ondo students and 3.44 for Oyo students. These results indicate that both groups had good scores for every factor. In order of the Ondo students scoring, the four LA factors were peer adjustment, family adjustment, school adjustment, and personal adjustment. For Oyo students, the order of scoring was peer adjustment, family adjustment, school adjustment, and family adjustment.

Thirdly, Pearson correlation coefficients measured the correlations between the dependent and independent variables. Positive and significant correlations, $(\mathrm{r}=+0.54$, and $\mathrm{r}=+0.76)$, were found in the scores of both the EII and LAI, respectively for students of Ondo and Oyo. These correlations are statistically significant at ( $\mathrm{p}<0.05)$. This finding is in line with those of Farn, Ying, and Chia (2006), who proposed that emotional intelligence is a significant predictor of life adjustment, school adjustment and family adjustment. However, the finding of Ogoemeka (2009) contradict the present finding, that emotional intelligence is not a strong predictor of adjustment, i.e., to say that an individual can adjust properly without necessarily being emotionally intelligent.

Furthermore, a survey on schoolwork activities showed that Ondo students have a less favorable environment for school-work activities, with features like dilapidated buildings and non-ventilated classrooms hindering effective learning while Oyo students have a more favorable environment for teaching and learning. Both groups indicated interests in pursuing further studies in top tertiary institutions.

The researcher proposes that emotional intelligence and life adjustment are inseparable factors in students' day to day life. Beyond educational advantages, emotional literacy courses will help children to better fulfill their roles in life if introduced in schools; they would be enabled to become better friends, students, sons, and daughters, and in the future, they would be more likely to be better husbands, wives, workers, bosses, parents, and citizens.

While not every boy and girl acquires these skills to the degree that they do, we are all the better for it. As Tim Shiver put it "a rising tide lifts all boats... It's not just the kids with problems, but all kids who can benefit from these skills; these are an inoculation for life, whereby maladjustment will not set in."

\section{Recommendations}

On the basis of the above results, the following recommendations were made:

- Students' emotional intelligence and life adaptation are related. School administrators could introduce emotional literacy programs, which are needed especially acutely at a time when too many children lack the capacity to handle difficulties, listen, focus, feel responsible for their work, or care about learning anything that will buttress these skills will help in their education.

- $\quad$ Conduct a student consulting program to reinforce students' abilities of emotional control and integrate daily interaction with people in order to improve both inter and intrapersonal relationships.

- Emotional literacy programs should include special classes for parents to teach them about what their children are learning, not just to complement what is imparted at school but also to help parents who feel the need to deal more effectively with their children's emotional lives. That way, children will receive get consistent messages about emotional competence in all parts of their lives. 


\section{A Last Word}

Given the crisis faced by our children and us, given the quantum of hope preserved by courses in emotional literacy, we must ask ourselves the following question. Shouldn't we be teaching these most essential skills for life to every child, now more than ever?

\section{AUTHOR INFORMATION}

Obioma Helen Ogoemeka, The author is a prolific writer by the name Obioma Helen Ogoemeka, who hails from the eastern part of Nigeria. She earned her bachelor's degree in guidance and counseling in 2005 and her master's degree in Counseling Psychology in 2009. She worked for six years as a lecturer and researcher from November 2006 at Adeyemi College of Education in Ondo, Ondo State, Nigeria, but presently employed as a Lecturer in Guidance and Counseling at University of Nigeria, Nsukka where she lectures and conducts research. Her major research interest is in adolescents and youths. She has presented her research papers at both local and international conferences and belongs to such educational organizations as the Counseling Association of Nigeria (CASSON). Correspondence concerning this article should be addressed to Obioma Helen Ogoemeka, Department of Educational Foundations, University of Nigeria, Nsukka. E-mail: helenogoemeka@yahoo.com

\section{REFERENCES}

1. Adeyemo, D.A. (2004). Buffering Effect of Emotional Adjustment of Secondary School Students in Transition. Electronic Journal of Research in Educational Psychology 3, (2) 79-90.

2. Akinboye, J.O. (2003). Creativity, innovation and success. Ibadan: Striving-Horden Publishers Nigeria Limited.

3. $\quad$ Castella, D.N. (2001). Mastering Our Emotions. The Master Facilitator Journal 4 (2). 21-24.

4. $\quad$ Derlega, V.J. \& Janda, L.H. (1986). Personal adjustment: The psychology of everyday life (3rd ed.). Reading: Addison Wesley.

5. Dickens, W.T. (2006). “Cognitive ability.” S. Durlauf ed, The New Dictionary of Economics, New York: Warmer Books.

6. Elias, M.J. (2001). Easing Transition with Socio-emotional Learning. Principal Leadership, 1, (7), 23-28.

7. Farn, S.C. Ying M.L. \& Chia, A.T. (2006). A Study of the Emotional Intelligence and Adjustment Behaviour of High School Students. World Transaction on Engineering and Technology Education, 5 (3) 473-476.

8. Goleman, D. (1995). Emotional intelligence: Why it can matter more than IQ. New York: Bantam Books.

9. Gottman, J.M., Katz, L.F. \& Hooven, C. (1997). Meta-emotion: How families communicate emotionally. Hillsdale: Lawrence Erlbaum Associates.

10. Ogoemeka, O.H. (2009). Correlates of social problem-solving and adjustment among secondary school students. [Unpublished master's thesis]. Nigeria: University of Ibadan.

11. Ogunyemi, A.O. (2008). Measured Effects of Provocation and Emotional Mastery Techniques in Fostering Emotional Intelligence among Nigerian Adolescents. Electronic Journal of Research in Educational Psychology, 6(2) 281-296.

12. Salovey, P. \& Meyer, J. (1990). Emotional Intelligence. Imagination, Cognition and Personality, 9, 185211.

13. Tallent, N. (1978). Psychology of adjustment. New York: Van Nostrand.

14. Wanichbuncha, K. (2001). Multi factor analysis. Bangkoki: Chulalonykoorn University Press.

15. Yong, L.M. (2001). Emotional intelligence (EQ) for innovative teamwork and corporate transformation. [presentation]. RAYMA Management Consultant Organized Workshop, April 25-26, 2001, Petaling-Jaya, Malaysia. 
NOTES 